\title{
The Research Methodology of the "Poetics" Scientific Category of Bashkir Fables
}

\author{
Gulkay Samirkhanova ${ }^{1}$, Zaituna Sharipova ${ }^{2}$, Gul'nur Bukharova ${ }^{3}$, Gadilya Bulyakova ${ }^{1}$, Rida Latypova ${ }^{1}$ \& \\ Louisa Suleymanova ${ }^{1}$ \\ ${ }^{1}$ Sibay Institute (branch) Bashkir State University, Sibay, the Republic of Bashkortostan, Russia \\ ${ }^{2}$ Bashkir State University, Ufa, the Republic of Bashkortostan, Russia \\ ${ }^{3}$ M. Akmullah Bashkir State Pedagogical University, Ufa, the Republic of Bashkortostan, Russia \\ Correspondence: Samirkhanova Gulkay Khaidarovna, Sibay Institute (branch) Bashkir State University, \\ Gornyakov st., 63/13, Sibay, the Republic of Bashkortostan, 453833, Russia. Tel: 8-937-491-6745. E-mail: \\ gulysib@mail.ru
}

\author{
Received: March 11, 2015 Accepted: March 30, 2015 Online Published: May 22, 2015 \\ doi:10.5539/res.v7n9p112 URL: http://dx.doi.org/10.5539/res.v7n9p112
}

\begin{abstract}
The paper reveals the issues of Bashkir fables poetics, in particular, definition of types of plot formation, detection of framework features, image classification, images characteristics evolution analysis, transformations under the influence of social environment. The main material for study is represented by the literary works of Bashkir writers and poets from the beginning of the $20^{\text {th }}$ century to date. The main findings are detection of actually Bashkir and borrowed fable plots, four types of plot formation of borrowed plots, definition of conflict types in Bashkir fables and images transformation tendencies.
\end{abstract}

Keywords: philology, education, literature, Bashkir literature, fable (masal, tamsil, amsal), moral, actually Bashkir and borrowed plots, types of plot formation, the law of definite composition and images idea, image transformation

\section{Introduction}

Bashkir literature is one of rich ancient literature with its own centuries-old traditions. At different stages of its development Bashkir literature distinguishes itself with ideological and thematic scope and genre originality. Appearance, establishment and change of genre system are intimately related to the development of literature history and artistic idea, which are conditioned by historic reality and social relations change. At the same time when genre system is being renewed in modern Bashkir literature some genres remain the same. Among the latter there's fable genre.

Bashkir fable along with other genres is considered in the works of such Bashkir scientists as Kharisov A. I., Akhmedyanov K. A., Kunafin G. S., Khusainov G. B. However as an individual literary issue it hasn't been a subject of special study yet. The volume of factual material in Bashkir literature is not estimated, genre evolution stages aren't defined. Fable genre specific features, its ideological and thematic diversity haven't been studied. Need for the study of Bashkir fable genre poetics in general, and the questions of theory and genesis of Bashkir fable, plot formation techniques, conflict and imaginative system characteristics in particular, determine the relevance of this study theme.

\section{Literature Review}

There are no individual monographies concerned with the poetics of fable genre in Bashkir literary studies. Researchers study theoretical material largely relating to genre hierarchy, genre nature and functions only together with other literary issues. When studying Bashkir literature of the $18^{\text {th }}-19^{\text {th }}$ centuries Kharisov A. I. remarks the didactic nature of fable (Kharisov, 1965), definition and characteristics of genre, differentiation of "masal" and "tamsil", imaginative system features are provided in the works of Akhmedyanov (2003), Khusainov (2006).

In their studies folklore specialists Barag and Zaripov emphasize the relation of fairytales about animals with fairytales of fable type: "in folklore of the majority of Turkic, Iranian, and Arabic nations a peculiar intergrowth of fairytales about animals with fairytales of fable type took place. Today it's impossible to demarcate them" 
(Barag \& Zaripov, 1989). Genre history development in Bashkir literature was most completely covered in the works of Kunafin $(1999,2004)$. The author, who studied establishing and development of fable genre in the second half of the $19^{\text {th }}$ - the beginning of the $20^{\text {th }}$ centuries considers fable a genre of narrative lyric poetry.

The researchers of Tadjik literature Levin, Rabiev and Yavich emphasize the antiquity of genre name origin (Levin et al., 1981). Thus, in ancient Classical Greek literature fables, parables, proverbs and sayings were named "ainos", then "apologue", "parabole" and "allegory". In Oriental art all these notions were named with a semitic word "mashal" and its dialectical derivative "amtal", "masa". Through Arabic the word "mashal" came into use among nations of Central Asia, as "masal" and "zarbulmasal" that meant "giving an example".

In Bashkir literature several terms were used to define small allegorical works of satiric nature: "masal", "amsal", "tamsil". All the three terms became a practice in Bashkir literary studies through Arabic language and relate to the verb "masala" (to be, appear, become; present oneself; resemble) and are translated as "model, example, ideal, comparison" or "proverb, saying, fable". "Amsal" translates to "worthy, great-class, excellent; ideal, exemplary", and it's also a plural of "masal". "Tamsil" is translated as "comparison" (Baranov, 1977).

All researchers admit the didactic citizenly nature, satiric pathos, and allegorism of fables (Krasovsky, 2005; Pospelov, 1971; Kozhevnikov \& Nikolaev, 1987; Kormilov, 2000; Khusainov, 2006; Kvyatkovsky, 1966; Introduction to literary studies, 1983; Dalgat, 1947), but differ in the issue of source materials, generic assignment of the genre and text organization types.

When defining the main characteristics of the genre Hegel (1999) in his works remarks that "the first demand placed on fable should involve a certain case that has to teach a moral, which would not only be fictitious, but being fictitious would comply with the type and nature of actual existence of such events in nature".

The researchers of Tadjik literature Levin I., Rabiev J. and Yavich V. qualify fable as cumulative or "formulaic" type of stories, the main of which is not plot, but structure, and define it as a synonym of fairytales about animals and proverbs (Levin, Rabiev, \& Yavich, 1981).

Many scientists agree that in the ancient world such genres as fable, fairytale, anecdote, riddle, and proverb were perceived as something general and largely referred to rhetoric than to literature (Levin, Rabiev, \& Yavich, 1981). It is also known that in the days of M. Lomonosov fable was traditionally referred to not to genres but the category of proofs established by rhetoric (About satire mastership, 1964).

Dalgat (1947), Pospelov (1971), Bashkir researcher Akhmedyanov (2003) refer fable to an epic type of literature. Vigotsky L. S., who also adheres to this opinion, emphasizes inhesion of catharsis (Tamarchenko, Tyupa, \& Broitman, 2008).

Such scientists as Kvyatkovsky (1966), Mescheryakov, Kozlov, Kubareva, Serbul, Tomashevsky (2000), Bashkir researcher Kharisov (1965) class fable as a lyric type of literature. According to Eliseev, Polyakova (2002), Bashkir researcher Kunafin (2004), Khusainov (2006) fable belongs to both epic and lyric type of literature. In such a way it's stated in Big literary encyclopedia edited by Krasovsky V. E that this genre organically merges features of epic works and some features of lyric works: epic nature is largely expressed in plots and characters, and lyrical nature - in author's assessment, but "the purpose of fables' authors is not to express their inner world: fable writer's attention is compelled to the outer world, it is the world he assesses from a perspective of "the proper" and "the improper", "the permissible" and "the impermissible" (Krasovsky, 2005).

Belinsky (1948), Lunacharsky A., Timofeev L., Borev Y., Makaryan A. (Nikolaev, 1962) distinguish satire as an individual type of literature and consider fable one of its ancient genres. In his turn, Pospelov G. N. refers satire, as a genre, and fable to ethological ("describing moral") literature: “....in ethological type of artistic content individual acts as a specific expression of essential features of life in his ambient, as its individual representative, its average individual, who in the long run completely lacks his personal inherent worth" (Pospelov, 1971).

Thus, the opinions of scientists regarding one or another type of literature vary. The analysis of Bashkir fables allows us to confirm the natural combination of epic and lyric components in the works of this genre.

\section{Materials and Methods}

\subsection{Bashkir Fable: Theory, Genesis and Ideological Aesthetic Resources}

Propp (1969) states that examination of any genre suggests above all its historical genesis and structure. The most ancient literary texts of fables were excavated in Sumerian city Nippur about 2950 B. C. (Code of Tadjik folklore, 1981). However the appearance of fable is usually related to a name of legendary Classical Greek slave Aesop (6-5 centuries B. C.). In ancient Greece Aesop's name prevailed through folklore works, and his image became a folklore character. Researchers leave open the possibility that the fabler was a historical figure 
(Armazastseva \& Nikolaeva, 2000). According to other scientists, fabular art originated in Ancient India (Rogatko, 1994). Jatakas and Sanskrit collections "Panchatantra", "Khitopadesha" "Twenty five stories of Vetala" and others are considered the most ancient and main compilation of works of fabular type.

Jatakas are stories of Buddha's reincarnation. They were written in the $1^{\text {st }}$ century B. C. in Pali language considered a sacred language of Buddhism in India and Ceylon. As a rule, folk plots were the basis of Jatakas.

The buddhists introduced the image of Buddha into folk stories and saturated them with "Buddhistic spirit", they substantiated their learning using the previous stories or plots (Nikitina, Paevskaya, \& Pozdneeva, 1962). According to the scientists the "Panchatantra" ("Pentateuch") collection was complied in Kashmir in III в. B. С. Its purpose was to "put ignoramus czarevitch wise" using fables (Levin, Rabiev, \& Yavich, 1981).

Classical Greek and ancient Indian fables enjoyed wide occurrence and development in the literature of other nations.

According to Kunafin G. S., the genre of fable, origins of which ascend to folklore, came up the peculiar way of establishing in Bashkir literature and in the first half of the $19^{\text {th }}$ century its genre features formed: "in the first half of the $19^{\text {th }}$ century the genre of fable in Bahkir oral tradition, ripening within small didactic genres of folklore (fairytales about animals, fairytales - parables, anecdotes-kulyamyas, proverbs and sayings) and interacting with them, gradually acquired its esthetics and artistic boundaries and genre features".

As the researcher notes, the process of realistic tendencies strengthening in oral tradition contributed to fables separation from fairytales: "By this time some fairytales about animals and parables with a didactic accent began to lose their genre attributes: beginning and ending, elements of mythology, fantasy, and descriptiveness in main part" (Kunafin, 1999, 2004). Moral content acquires the form of satire components. The author also associates "sudden revival and development of protreptic and moral genres" with the process of development of educational activity in Bashkortostan. Bashkir poets and writers begin to take interest in personality and person's inner world, the idea of natural equality of men is discernible in their works. Kargaly A., Salikhov H., Akmullah M., Umetbaev M. were the first who addressed the most pressing conflict of that time - the conflict between mazlums and zalims (Sharipova, 2008).

Kunafin G. S. states that new forms are needed to express new social relations, such "high" genres as dastan, madkhiya, kubair are replaced with "low" genres of protreptic nature of fabular type. Strengthening of economic, cultural, and literature relations of Russia and Bashkortostan also contributes to their development. Plots from Russian, and through Russian ones from other European literature pass into Bashkir fables plot content. The researcher notes that small didactic, moral-descriptive genres in the period of self-determination had no clear distinctions, they were characterized by syncretism. This idea is also favoured by folklore specialists Barag, Zaripov (1989).

Thus, the genre of fable in Bashkir literature, ripening within folklore works, acquired its genre features in the first half of the $19^{\text {th }}$ century. Originally it was works of didactic, moral nature of small volume. With a shift from old feudal to new capitalist relations the strengthening of realistic tendencies in Bashkir literature takes place. The genre of fable is gradually separating from fairytales about animals acquiring peculiar content and fabular form, pure moral teaching takes second billing, the elements of satire are introduced, narration takes social marking.

\subsection{Features of Plot Formation of Bashkir Fables}

Regarding plot composition of Bashkir fables it's possible to distinguish actual Bashkir and borrowed plots related to literary monuments of fabular art—Aesopian fables, ancient Indian collections "Panchatantra", "Kalila i Dimna", etc. (Barag \& Zaripov, 1989)

Actually Bashkir plots of fables are intimately connected with people life. Several characteristics incident to actual Bashkir plots of fables can be pointed out:

1) The historic reality of Bashkir people's life is embodied in plots. Indeed, Umetbaev M. in his fable "The Belt and The Bast" addresses social relations of the end of the $19^{\text {th }}$ century, to the problem of zalims and mazlums; while Gafuri's ("The Bat and The Swallow", "The Ass"), and Babich's ("Tamsil", "The Goat and The Pig") fables plots reflect dissemination of educational ideas in Bashkortostan. Social disparity and colonial policy are exposed in Gafuri's fables "The Needle and The Thread", "The Dog and The Hare", "Who Ate The Sheep?", dissemination of revolutionary ideas in Bashkortostan is revealed in Babich's "The Island", "Nursery rhymes", "The Fable Denouement". This feature is also traced in fables of poets of the middle of $20^{\text {th }}$ century. In Imangulov's "Dispute at the Farm" an old mare "looks back" into the heroic past of its grandfathers, how they fought Napoleon, how they came to Paris, how they took Berlin; 
2) Plots make use of motives related to ancient Bashkir mythology and demonology. For example, imaginative parallel of an unreliable friend and serpent named Yuha is given in Imangulov's "The Shadow". According to ancient beliefs, a Bashkir snake that has lived through 100 years turns into Yuha ylan and can disguise. A hard-working honest man appears as Sun Mother Akbuzat known from Bashkir mythological plots in the "Wrote an Order" fable of the same author. Poets refer to mythological plots of ancient epos and use images known to folk as embodiments of the good and the bad.

There are other mythological names: jinns, div-pari (F. Gumerov's "False and Truth"); water spirit, windmaster (Sh. Babich's "The Swans"); gluttonous old woman (S. Imangulov's "The Silly Cow"); the mythological toponym of Kaf tau — the highest mountain, behind which all kinds of devilry lives (Sh. Babich's "The Island") and others.

3) Religious views, traditions and customs of Bashkir people are embodied in plots. For example, Gilyazhev's "Envious Hen" plot is based on one of Bashkir ancient beliefs. Up to this date people believe if one or another animal makes something untypical for its sex it will make no good. Gilyazhev's fable is about the Hen who envies to the Rooster, she begins to want the same respect. She begins to crow in the mornings, tries to run after hens, to do everything to be like the Rooster. However, the Hen had to forfeit its life: according to ancients believes master of the house slaughtered it.

The expression "To one's own harm!" is popularly used in relation to a very avid and greedy person, who disregards blood relations, friendship and freedom of other people for the sake of his sordid motives. If what is said is true such behavior is always punished. This belief is also applied in Dayan's "The Black Raven in a Pigeon-hole" (Dayan, 1965) and Gumerov's "The Boot" fables.

In Bashkir fables beasts and animals also have statuses of mullahs, khazrats, ishans, they also believe in one God (Gafuri's "The Bat and The Swallow"), call out azan, read namaz, fastening sawm (Gafuri's "The Animals Sick of the Plague", Nigmatullin's "Goose's Judgement", Imangulov's “Today We Have Sawm”, etc.). They live and judge by the shariah laws (Gafuri's "The Bull and The Wolf"), different shaytans mislead them (Bikkul's "The Burbot is Punished, The Gudgeon Has Stayed Uninvolved", Gumerov's "False and Truth", etc.). And in Imangulov's "When a Deputy was Elected" haram and khalyal were distinguished for Bashkir people. It's commonly known these notions are from Muslim religion.

There are also such plots, wherein the moral is drawn from actions that took place in Bashkir reality. These are Gareev's “The Lonely Mare” (Gareev, 1959), Nigmatullin’s “Mole the Winner”, Imangulov's “Brave Pug”, etc. In these fables the actions take place during the national holiday sabantuy. The detailed description of national wresting kuresh, awarding the winner with an embroidered towel is given. Bashkir marriage (Babich's "Tamsil", Nigmatullin's "Black Vulture's Grief"), funeral (Arslan's "Why the Fox Hung Herself") traditions, the ritual of name giving (Imangulov's "The Family of Myyaubuka") are also mentioned.

4) There is evidence for traditional households of Bashkirs almost in each fabular plot of poets of different years. Their characters are engaged in horse breeding, beekeeping, wild-hive beekeeping, etc. (Karim's "Announcements and The Hares", Imangulov's “We Knew of Much Nectar", "Bends, Indeed!").

5) Ethnoculturological lexis plays a great role in national space formation. In actual Bashkir plots names of national dishes, national costume, tableware, musical instruments, generic and tribal division, kinship terms are widely used.

Thus, the ancient genre of satiric poetry fable is evolved in a peculiar way in the creative works of Bashkir poets. They managed to reflect the national identity along with universal morals in their works.

On a new plane borrowed plots cross traditions of local literature and folklore, providing artistic contacts with creative nature, and a work - with national colour. Borrowed plots are developed in a number of ways. The analysis of Bashkir fables allows distinguishing four types of plot formation:

1) Plots are translated into the Bashkir language without any changes while preserving the idea, the motive, the plotlines, and the imaginative system. For example, such poets as S. Yakshigulov ("The Monkey and Glasses"), Gafuri M. ("The Monkey and Glasses", "Grasshopper and Ant"), Imangulov's ("The Fox and The Ass", "The Mirror and The Monkey", "One who Casts Dirt into the Well", "Everlasting love", etc.) provide close translations of I. A. Krylov's and S. Smirnov's fables, in such a way directly presenting Russian literary works to readers.

2) Certain plots are creatively remade while preserving the plotlines and the motive, but the imaginative system is replaced by Bashkir reality elements. M. Gafuri's "The Animals Sick of the Plague" is borrowed from Krylov I. A. ("The Animals Sick of the Plague"), who creatively processed La Fontaine's fable "The Animals Sick of the 
Plague", which in its turn, ascends to the legendary Aesopian fables. In the Krylov's fable vulturous "judges" are popes, all but saints, and while in the Gafuri's fable the Lion is titled as a hazrat. Fearful animals sawm fast, begin to read namaz and ayats, become hazrats, pray for their sins.

3) Certain plots are creatively remade while preserving the main idea and the plotline and completely changing the imaginative system. In such a way, Imangulov's in his "Today we have Sawm" retains the plotline, but changes the imaginative system. The characters of this fable are the Cat and kazylyk-sausage. While nobody's at home the old cat gets into the pantry and notices a kazylyk-sausage on a nail. The old idler foretastes a tasty dinner, but cannot get it. Eventually, the cat has to comfort himself with the fact that today it's sawm fasting.

4) Certain plots are creatively remade while changing the plotline and providing the imaginative system with a new idea. The well-known plot "The Fox and The Grape" is widely popular among Bashkir fables. It's an ancient plot known since the days of La Fontaine ("The Fox and the Grapes") and Phaedrus ("The Fox and a Bunch of Grapes"), it can be found in Krylov's adaptations ("The Fox and the Grapes") and related to the proverb "it catches your eye, but you can't catch it". In 1979 Gareev Yu. addressed the same plot ("The Fox and the Grapes"). According to Krylov's plot once hungry Fox steals in a garden and catches a sight of juicy bunches of grapes. The Fox's eyes and teeth are itching, but she cannot get them, they hang too high. She endeavours a whole hour, but has to go away, consoling herself with the thought that the grape is green ("They're probably sour anyway", and proceeded to walk away"). According to Gareev Yu., the "red thief-fox" instead of walking away takes her hungry fellows to the garden. They take a ladder and get the grape, not a berry remains after them! There's a new image in the fable - the Crow, who, as it happens, knows the text of Krylov's fable. She remarks that they act regardless the traditional plot. To which Gareev's Fox replies that the times have changed and she is not the Fox of the past, but the "new" Fox.

Thus, famous plots are represented in Bashkir poets' works in close translation while preserving the idea, the motive, the plotline and the imaginative system, or are creatively remade. External traditional plots and motives, imaginative systems are transformed in the context of new reality conditions within the traditions of national literature.

\subsection{The Peculiarities of Composition and Conflict of Bashkir Fables}

The composition of any literary work is attributed to the notion of conflict. It is the development of conflict, the collision of the characters' interests, that defines the work structure. The analysis of Bashkir fables allows us to distinguish two types of conflict: the clash of a positive phenomenon with a negative one and the clash of a negative with a negative. The fables of the end of the $19^{\text {th }}$ century, which reveal mazlums' oppression by zalims, (Umetbaev's "The Belt and The Bast”; Gafuri's “The Wolf and the Bull”, "Who Ate the Sheep?", etc.), or which are related to educational ideas dissemination, exposing ignorance, greed, prudishness, avidity, lack of culture (Babich's "The Goat and The Pig", "Tamsil", etc.) are the striking examples of conflict development. However, there are a lot of fables with no positive characters, their failure is demonstrated in the clash of the old with the old, the negative with the negative. Thus, in Bagumanov's "New Version of Old Fable", Basimov's "Akbay, Karabay and Alabay", Imangulov's "Love is Blind", etc. mutual exposure and self-exposure of characters are observed.

As a rule, the exposition in fables is cut to a minimum, only one sentence in it may point out the main characters, the scene and the time of the action. The narration begins with entanglement, the fabular characters are in full play. The climax, the moment of clash of the characters' interests, is the second part. The dynamism of events intensifies the fable's influence on the reader. The detailed description of time and place of events, description of principal characters, usually in the form of satiric portrait, can only be found in prosaic fables of recent years.

In Bashkir literature there are also fables of chain composition. In such a way, Gafuri's fable "The Cat and The Mice" can be treated as two independent plots. In the first part the conflict between zalims and mazlums is revealed through the images of the Cat and the Mice, a new plotline is developed in the second part, where a new image is introduced - the image of the Host. The last part reflects all the author's hopes for changes in mazlums' situation. The Cat's image is a link between the plotlines.

\subsection{The Imaginative System of Bashkir Fables}

The analysis of the imaginative system of Bashkir fables allows distinguishing ten groups of characters: wild animals, domestic animals, birds, insects, amphibians and water-birds, trees and plants, inanimate objects, abstract notions, man and parts of his body, we could distinguish mythological characters as Akbuzat, Yuha ylan, En pari, etc. as a separate group. 
Oral tradition of each nation is connected to its aesthetic perception of the world and is distinguished by its imaginative system. Pospelov states that personalities of traditional characters do not develop in fables, they are carriers of established, constant moral and largely negative qualities (Pospelov, 1971).

The images of animals from ancient fairytales passed into fables. Their periphrastic sense turning into allegory and symbolizing moral qualities of people, has a traditional, clear meaning: in fables a fox personifies a cunning and greedy person, a wolf - a rough, authoritative, blood-thirsty, a bear - a stupid, a hare - a coward person.

According to scientists, fabular allegorical image always has its role, and, as a rule, each character has its anti-image (Arhhipov, 1974). According to the "law of definite composition" of fabular image, each character only acts in line with its own role and usually together with a certain character: the Wolf- the Hare, the Wolf - the Lamb, the Eagle - the Sparrow, the Crow - the Nightingale. As a rule, the base of couple formation is opposition of the power and the lack of power, etc.

Arhhipov V. A. states this law is true for all fabular characters. The majority of Bashkir fables confirm this conclusion. However there are a lot of examples with broken law of definite composition or where animals' actions are inconsistent with their roles that leads to the change of image idea. This phenomenon becomes a peculiar technique to attract the reader's attention to acute problems of society and is widely used in the creative works of such poets as Gafuri M., Babich Sh., Imangulov S. and others.

Transformation, change of image idea, can take place in two directions: from the negative to the positive, and vice versa.

Babich's "Kind of Fable" can be referred to the first type. Here the mice and the rats personify oppressed people. They establish their own order under the ruins of a house according to which all have equal rights. In such a way the development of revolutionary ideas in Bashkir society in the beginning of the $20^{\text {th }}$ century is demonstrated. Gafuri's fable "The Cat and The Mice" also has the image of oppressed people. The poet of his time reveals the fate of mazlums.

The fabular creativity of the Bashkir poet S. Imangulov is generally based on violation of coupling rules and their roles' change, i.e. one or another animal plays an opposite part. For example, in the fable "Beside the Brook", which is the adaptation of the famous Krylov's plot "The Wolf and the Lamb" the roles of main characters are dramatically changed. The Wolf is fatherly careful, he asks careless Lamb not to drink from the brook: all rivers and brooks are contaminated with processing waste and garbage. The moral of the ancient plot "the stronger always blames the weaker" gets a totally new formula "the stronger cares for the weaker".

In his another work "How the Fox Shamed Herself" the poet addressed to the well-known plot "The Crow and The Fox", which can be found in the adaptations of Tredyakovsky V. K., Sumarokov A. P., Heraskov M. M., and Krylov I. A. and ascends to the fables of Aesop, Phaedrus and La Fontaine (Fables, 2000). According to the ancient plot the Crow succumbs to Fox's sweet words and drops the cheese, staying without breakfast. In Imangulov's fable the Crow responds that the times when she was deluded with silken words have passed. She says grinning that she can give a treat to her, the only thing the Fox needs is to come "not empty-handed". It turns out that Crow's husband is a chief storekeeper. Surprised with such an answer the Fox has to go away high and dry. Through the change of images' traditional roles Imangulov S. calls the readers' attention to such acute problems of modern society as alcoholism, bribery, corruption.

The second type of transformation can be defined as a change of image idea from the positive to the negative. Many Imangulov's fables involve this technique. For example, according to the "Between Birds" plot the Swan gives generous sweet words and courtesies before the wedding with the Eagle. However everything changes when family life gathers pace: the Swan pecks out Eagle-husband's eyes. In oral tradition of Bashkir people the Swan, a sacred bird, is always given virtues, but in this fable the poet, addressing this image, attacks new social relations, detracting of man's role and status in the family and childrearing.

In another fable "The Gold-Fish" the poet disregards the role of the goldfish and reveals the mismatch of person's good looks with his spiritual riches. The plot development of the fable comes to fishermen who wonder and argue about goldfish's feed. According to their opinion she should eat something special as distinct from other fish. However, it turns out that her belly's full of worms.

Poets frequently violate "the law of stable pairs". For example, Gafuri's "The Dog and the Hare" reveals the impossibility of friendship between The Dog and the Hare, that confirms the unreality of zalims and mazlums reconciliation for once more: the strong and the oppressed will never have equal rights.

There are also a lot of fables where the principal characters are animals not interacting with each other in real life. In Imangulov's "Love is Blind", "How Abay was Choosing His Wife", "Wolf in Love" wrong situations are 
described through knowingly incongruous couples. It turns out that such situations make no good. In such a way the Owl and the Hen suffer love torments since the Owl cannot see in the day time, the Hen - in the night; Akbay who married the She-Wolf was eaten by her, and the Wolf who fell in love with the Fox lost his home. The unnatural composition of fabular couples and their roles' change destroy their lives, since they ignore the experience of people, the established forms of happy existence.

Thus, the change of characters' roles and breach of definite composition become a peculiar technique in the creativity of Bashkir poets.

\section{Results and Conclusion}

The paper presents the first system study of plot and compositional structure of Bashkir fables in terms of fables. The term "poetics" came from the ancient literature, from Aristotle. The meaning he implied is relevant up to our days: poetics is "a part of philology concerned with the description of the historic and literary process, the structure of literary works and their systems of aesthetic means". The research subject is the literary works of Bashkir authors from the beginning of the $20^{\text {th }}$ century to date, and research tasks - their plot and compositional structure methods study. When defining the scientific category of "poetics" of Bashkir fables specific scientific methodology was applied with the use of the principles of unity of theory and practice, consistency, creative and concrete historical approaches. The main theoretical methods of the study are analysis, substantiation, and induction.

The genre of fable in Bashkir literature undergoes peculiar stages of evolution. Regarding the plot composition of Bashkir fables actual Bashkir and borrowed plots can be distinguished. Four types of plot formation can be pointed out in borrowed plots: close translation while preserving the main idea, the plotline and the imaginative system; creative adaptation while preserving the plotline and the motive and changing the imaginative system with Bashkir reality elements; creative adaptation while preserving the main idea and the plotline and changing the imaginative system completely; creative adaptation with the change of the plotline and provision of the imaginative system with a new idea.

The imaginative system of Bashkir fables includes ten groups of characters: wild animals, domestic animals, birds, insects, amphibians and water-birds, trees and plants, inanimate objects, abstract notions, man and parts of his body, separate group is comprised of images relating to Bashkir nation's mythology. The majority of Bashkir fables confirm the law of definite composition and images idea. However there are a lot of examples when definite composition is broken or animals act in contradiction with their roles that leads to the change of image idea - the transformation of images.

\section{References}

About satire mastership (Issue 2, p. 280). (1964). Frunze: Kyrgyz State University.

Akhmedyanov, K. A. (2003). Literature theory (in Bashkir) (p. 392). Ufa: Kitap.

Arhhipov, V. A., \& Krylov, I. A. (1974). Folk wisdom poetry (p. 288). Moscow: Moskovsky rabochy.

Armazastseva, I. N., \& Nikolaeva, S. A. (2010). Children's literature (p. 472). Moscow: Akademia, Vysshaya shkola.

Baranov, H. K. (1977). Arab-Russian dictionary (5th ed., p. 944, revised and enlarged). Moscow: Russky yazyk.

Bashkir folk art. (1989). Wonder stories—Fairytales about animals (Vol. 4, p. 512). Ufa: Bashkirskoe knizhnoe izdatelstvo.

Belinsky, V. G. (1948). Collected works (Vol. 3). Moscow: Goslitizdat.

Krasovsky, V. E. et al. (2005). Big literary encyclopedia (p. 845). Moscow: "Slovo" philological association: Olma-PRESS Obrazovanie.

Dalgat, U. B. (1962). Folklore and literature of Dagestan (p. 206). Moscow: Izdatelstvo Vostochnoy Literatury.

Eliseev, I. A., \& Polyakova, L. G. (2002). Dictionary of literary terms (p. 320). Rostov-on-Don: Feniks.

Rogatko, N. P. (1994). Fables (p. 304). Moscow: ART+N.

Code of Tadjik folklore. (1981). Fables and fairytales about animals (Vol. 1, p. 389). Moscow: Nauka.

Harisov, A. I. (1965). Literary heritage of Bashkir nation (in Bashkir) (p. 416). Ufa: Bashkirskoe knizhnoe izdatelstvo.

Hegel, G. W. F. (1999). Esthetics (Vol. 2, p. 603). St. Petersburg: Nauka. 
Introduction to literary studies. (1983). Moscow.

Khusainov, B. G. (2006). Theoretical literature terms dictionary (in Bashkir) (p. 248). Ufa: Kitap.

Khusainov, G. B. (2006). The poetry of Bashkir literature. In Theoretical poetics (in Bashkir) (p. 403). Ufa: Gilem.

Krylov, I. A. (2000). Fables (p. 219). Moscow: Children's literature.

Kunafin, G. S. (1999). With both song and satire-The genre system development of Bashkir literary song and satiric poetry of the $19^{\text {th }}$ - the beginning of $20^{\text {th }}$ centuries (p. 256). Ufa: Kitap.

Kunafin, G. S. (2004). Poetic echo of the past-The genre system development of Bashkir manifestational \& publicistic and narrative poetry (p. 316). Ufa: Kitap.

Kvyatkovsky, A. P. (1966). Poetic dictionary (p. 376). Moscow: Soviet encyclopedia.

Kozhevnikov, V. M., \& Nikolaev, P. A. (Eds.). (1987). Literary encyclopaedic dictionary (p. 752). Moscow: Soviet encyclopedia.

Mescheryakov, V. P., Kozlov, A. S., Kubareva, N. P., \& Serbul, M. N. (2000). Literary studies basics (p. 372). Moscow: Moscow lyceum.

Kormilov, S. I. (Ed.). (2000). Modern dictionary—Reference book on literature (p. 704). Moscow: Olymp: LST Press JSC.

Nikitina, V. B., Paevskaya, E. V., Pozdneeva, L. D., \& Reder, D. G. (1962). The literature of Ancient Middle East (c. 467). Moscow: Moscow University Press.

Nikolaev, D. (1962). Laugh-The artillery of satire (p. 224). Moscow: Iskusstvo.

Nikolina, N. A. (2003). The methods of author's position expression in literary text: Heading, keywords, proper names, remarks. In Text philological analysis (p. 256). Moscow: Akademia.

Pospelov, G. N. (1971). The problems of literature historical development (p. 271). Moscow: Prosveschenie.

Propp, V. Y. (1969). The morphology of a fairy tale (2nd ed.). Moscow.

Sharipova, Z. Y. (2008). Bashkir literary idea (in Bashkir) (p. 320). Ufa: Kitap.

Tamarchenko, N. D., Tyupa, V. I., \& Broitman, S. N. (2008). Art discourse theory. In Theoretical poetics (3rd ed., p. 512). Moscow: Akademia.

Tomashevsky, V. B. (2001). Literary theory. In Poetics (p. 334). Moscow: Aspect Press.

\section{Copyrights}

Copyright for this article is retained by the author(s), with first publication rights granted to the journal.

This is an open-access article distributed under the terms and conditions of the Creative Commons Attribution license (http://creativecommons.org/licenses/by/3.0/). 